\title{
Diallyl sulfide down-regulates polycyclic aromatic hydrocarbon-induced cytochrome P450 1A1 in mouse liver and lung
}

\author{
Young-Sook Hong ${ }^{1,3}$, Hae-Young Park ${ }^{1}$ and \\ Sang-Shin Park ${ }^{2}$ \\ 1 Department of Biochemistry, College of Medicine \\ Ewha Womans University, Seoul 158-056, Korea \\ 2 Occupational Diseases Diagnosis and Research Center, \\ Industrial Health Research Institute, Incheon 403-120, Korea \\ 3 Corresponding author
}

Accepted 19 November 1996

Abbreviations: CYP, cytochrome P450; EROD, 7-ethoxyresorufin-O-deethylase

\begin{abstract}
The expression of cytochrome P450 genes directly within target cells is an important determinant of human susceptibility to cancers and other chemically initiated diseases. One pivotal gene, CYP1A1 codes for an inducible cytochrome P450 isozyme $1 \mathrm{~A} 1$ responsible for the bioactivation of numerous carcinogenic polycyclic hydrocarbons. In the present study, the effects of 3-methylcholanthrene, a polycyclic aromatic hydrocarbon, on the activity and expression of CYP1A1 and the protective effects of diallyl sulfide on 3 methylcholanthrene-induced changes in mice liver and lung were investigated. After a four daily 3methylcholanthrene-treatment $(25 \mathrm{mg} / \mathrm{kg}$, i.p.), liver and lung microsomal 7-ethoxyresorufin- $O$ deethylase (EROD) activity, associated with CYP1A1, was increased. A corresponding increase in the level of CYP1A1 mRNA was observed in mouse liver and lung after 3-methylcholanthrenetreatment by Northern blot analysis. Diallyl sulfide reduced 3-methylcholanthrene-induced CYP1A1 mRNA expression and its associated EROD activity in mouse liver and lung. The modulation of CYP1A1 mRNA by 3-methylcholanthrene and diallyl sulfide was mainly due to transcriptional regulation.
\end{abstract}

Keywords: diallyl sulfide, cytochrome P450, carcinogen, 3-methylcholanthrene, mouse, liver, lung

\section{Introduction}

The cytochrome P450 (CYP) superfamily of isozymes is involved in the metabolism of a diverse range of compounds (Nebert et al., 1991). The CYP1A subclass of this family consists of two members, CYP1A1 and CYP1A2, which are responsible for the metabolism of many xenobiotic compounds, including drugs, carcinogens, mutagens, dietary components, and environmental pollutants (Black and Coon, 1987). Carcinogenic compounds, such as benzo(a)pyrene and benzanthracene are metabolized preferentially by CYP1A1, whereas aflatoxins and arylamines are metabolized by CYP1A2 (Aoyama et al., 1990). These enzymes are implicated in both carcinogen detoxification and activation (Butler et al., 1989a,b; Santhanam and Lotlikar, 1989; Aoyama et al., 1990). The polycyclic aromatic hydrocarbons have been shown to elicit prolonged biochemical responses in several rodent species, particularly induction of mixed function oxygenases in hepatic tissue. Lung is also of interest since polycyclic aromatic hydrocarbons have been demonstrated to have tumor promoting effect, increasing the numbers of lung tumors in Swiss mice initiated with $N$-nitrosodimethylamine.

Diallyl sulfide, a compound derived from garlic, has been shown to inhibit chemically induced carcinogenic and cytotoxic responses in rodents. Inhibition of the CYP enzymes responsible for the metabolic activation of the carcinogenic and toxic chemicals is believed to be a major mechanism of the observed chemopreventive effect of diallyl sulfide. diallyl sulfide has been shown to reduce the incidence of a variety of carcinogen-induced tumors, including those induced by polycyclic aromatic hydrocarbons. Investigations of these anticarcinogenic actions have demonstrated that diallyl sulfide inhibits the CYP-dependent activation of the polycyclic aromatic hydrocarbon benzo(a)pyrene. The present study was therefore designed to investigate the effects of 3-methyl-cholanthrene on the activity and expression of CYP1A1 and the protective effects of diallyl sulfide on 3-methylcholanthreneinduced changes. Results obtained from this study will be useful to evaluate whether diallyl sulfide could be a useful chemopreventive agent to reduce 3methylcholanthrene-induced lung tumori-genesis in mice.

\section{Materials and Methods}

\section{Materials}

$\left[\alpha-{ }^{32} \mathrm{P}\right] \mathrm{dCTP}(3,000 \mathrm{Ci} / \mathrm{mmol})$ and $\left[\alpha^{32} \mathrm{P}\right] \mathrm{dUTP}(3,000$ $\mathrm{Ci} / \mathrm{mmol}$ ) were obtained from Amersham (Bucking- 
hamshire, U.K.). All other chemicals were obtained from Sigma Chemical (St. Louis, MO).

\section{Animals}

Male ICR mouse weighing 30-35 g were housed in polycarbonate cages and had free access to standard laboratory mouse chow and water. 3-methylcholanthrene animals were treated with four daily intraperitoneal injections of 3-methylcholanthrene in corn oil (25 mg/kg). 3-methylcholanthrene plus diallyl sulfide animals were treated with four daily intraperitoneal injections of 3-methylcholanthrene and a single intragastrical injection of diallyl sulfide (200 $\mathrm{mg} / \mathrm{kg}$ ). Control animals were injected with corn oil. Animals were sacrificed by cervical dislocation at $18 \mathrm{~h}$ after the last treatment.

\section{Microsome preparation}

Rat liver and lung microsomes were prepared by differential centrifugation (Hong et al., 1987). Protein concentration was determined by the method of Lowry et al. (1951).

\section{7-Ethoxyresorufin-O-deethylase (EROD) activity}

The dealkylation of ethoxyresorufin is sensitive and specific indicators of CYP $1 \mathrm{~A} 1$ activity and was quantified by fluorimetric analysis of the accumulation of resorufin at an excitation wavelength of $522 \mathrm{~nm}$ and emission wavelength of $586 \mathrm{~nm}$ (Burke et al., 1974, 1985). Resorufin standards were assayed daily and utilized to calculate specific enzyme activity.

\section{RNA isolation and hybridization analysis}

Total RNA was prepared by acid guanidinium thiocyanate-phenol-chloroform extraction (Chomczynski and Sacchi, 1987). For Northern blot analysis, RNA was electrophoretically separated in $1 \%$ agarose gel containing 2.2 $\mathrm{M}$ formaldehyde and blotted onto nitrocellulose filter. The nitrocellulose filter was baked at $80^{\circ} \mathrm{C}$ for $2 \mathrm{~h}$ in vacuo. For hybridization with cDNA probe, the filter was prehybridized for $3 \mathrm{~h}$ at $55^{\circ} \mathrm{C}$ in $5 \times$ Denhardt's solution $(1 \% \quad$ Ficoll, $1 \%$ polyvinylpyrrolidone, $1 \%$ BSA), $5 \times$ SSC, $0.1 \%$ SDS, 10 $\mu \mathrm{g} / \mathrm{ml}$ of denatured salmon sperm DNA, and $50 \%$ formamide. The filter was then hybridized in the same solution with the ${ }^{32} \mathrm{P}$-labeled cDNA probe $\left(2 \times 10^{6}\right.$ $\mathrm{cpm} / \mathrm{ml}$ ) overnight. The filter was washed at $65^{\circ} \mathrm{C}$ twice with $1 \times$ SSC- $0.5 \%$ SDS for $15 \mathrm{~min}$ each and then washed twice with $0.1 \times$ SSC- $0.1 \%$ SDS for $15 \mathrm{~min}$ each. Autoradiography was carried out by exposing the filters to Kodak XAR- 5 film at $-70^{\circ} \mathrm{C}$ with a Lightening plus intensifying screen. The bands on the autoradiographies were quantified a LKB densitometer.

\section{cDNA synthesis and RT-PCR}

Total RNA was subjected to reverse transcription (RT) and was then used in PCR experiments to generate partial cDNA probes for Northern blot analysis. Oligonucleotide primer set used to generate CYP1A1 cDNA probes were 5'-CCATGACCAGGAACTATGGG3' and 5'-TCTGGTGAGCATCCAGGACA-3'. Reverse transcription of RNA was performed in a final volume of $20 \mu \mathrm{l}$ containing $10 \mathrm{mM}$ Tris- $\mathrm{HCl}, \mathrm{pH} 8.8,50 \mathrm{mM} \mathrm{KCl}$, $0.1 \%$ Triton X-100, $5 \mathrm{mM} \mathrm{MgCl} 2,1 \mathrm{mM}$ of each dNTP, 20 units of RNase inhibitor, 15 units AMV reverse transcriptase, $0.5 \mu \mathrm{g}$ of oligo(dT) 15 and $1 \mu \mathrm{g}$ of total RNA. The samples were incubated at $42^{\circ} \mathrm{C}$ for $15 \mathrm{~min}$, and reverse transcriptase was inactivated by heating at $95^{\circ} \mathrm{C}$ for $5 \mathrm{~min}$. To these complementary DNA samples, a PCR master mix was added to adjust the final volume to $50 \mu \mathrm{l}$. For CYP1A1 analysis, the final concentration in the $\mathrm{PCR}$ reaction was $3 \mathrm{mM} \mathrm{MgCl}_{2}, 2.5$ units Taq polymerase, and $10 \mathrm{pmol}$ of forward and reverse primers. The reaction mixtures were heated at $95^{\circ} \mathrm{C}$ for $5 \mathrm{~min}$ and immediately cycled 30 times through a $1 \mathrm{~min}$ denaturing step at $94^{\circ} \mathrm{C}$, a $1.5 \mathrm{~min}$ annealing step at $54^{\circ} \mathrm{C}$, and a $1 \mathrm{~min}$ elongation step at $72^{\circ} \mathrm{C}$. Following the final cycle, a $5 \mathrm{~min}$ elongation step at $72^{\circ} \mathrm{C}$ was included. Aliquots of the PCR reaction were electrophoresed on $1.5 \%$ agarose gels, and PCR fragments were visualized with ethidium bromide staining.

\section{Nuclei preparation and run-on transcription assay}

Nuclei were purified by sucrose gradient centrifugation (Schebler et al., 1983). In brief, lung tissues were homogenized in $10 \mathrm{vol}$. of $0.3 \mathrm{M}$ sucrose in buffer $\mathrm{A}$ (60 $\mathrm{mM} \mathrm{KCl}, 15 \mathrm{mM} \mathrm{NaCl}, 0.15 \mathrm{mM}$ spermine, $0.5 \mathrm{mM}$ spermidine, $14 \mathrm{mM} \beta$-mercaptoethanol, $0.5 \mathrm{mM}$ EGTA, $2 \mathrm{mM}$ EDTA, $15 \mathrm{mM}$ Hepes, $\mathrm{pH}$ 7.5). The homogenate was filtered through six layers of cheesecloth, layered over a $10 \mathrm{ml}$ cushion of $30 \%$ sucrose in buffer $\mathrm{A}$, and spun down at $4^{\circ} \mathrm{C}$ for $10 \mathrm{~min}$ at $3,000 \mathrm{rpm}$ using a Sorvall GSA 600 rotor. The crude nuclei were resuspended in $3.5 \mathrm{ml}$ of $2 \mathrm{M}$ sucrose in buffer $B$ (same as buffer $A$, except that the EGTA and EDTA concentrations were reduced to $0.1 \mathrm{mM}$ ), layered over $2 \mathrm{M}$ sucrose in buffer $\mathrm{B}$, and sedimented at 36,000 rpm in a Beckman SW 50.1 rotor at $4^{\circ} \mathrm{C}$ for $1 \mathrm{~h}$. The clean nuclei were resuspended in the nuclei storage buffer (20 mM Tris- $\mathrm{HCl}, \mathrm{pH} 7.9,75 \mathrm{mM} \mathrm{NaCl}, 0.5 \mathrm{mM}$ EDTA, $0.85 \mathrm{mM}$ dithiothreitol, $0.125 \mathrm{mM}$ phenylmethylsulfonyl fluoride, $50 \%$ glycerol), sedimented for $2 \mathrm{~min}$ in a Eppendorf centrifuge at $4^{\circ} \mathrm{C}$, and resuspended in the nuclei storage buffer at a density of about $10^{6}$ nuclei per microliter. The nuclei was checked under a microscope. Nuclei were either used immediately for the in vitro transcription assay or stored at $-70^{\circ} \mathrm{C}$ for 
several weeks without loss of activity. The nuclear runon transcription assay procedure was done as described by Zelenka et al. (1989). In brief, $5 \times 10^{6}$ nuclei were incubated in $100 \mu \mathrm{l}$ of reaction mixture containing $25 \%$ glycerol, $5.8 \mathrm{mM}$ Tris- $\mathrm{HCl}, \mathrm{pH} 8.0,3$ $\mathrm{mM} \mathrm{MgCl} 2,173 \mathrm{mM} \mathrm{KCl}, 0.3 \mathrm{mM}$ each ATP, GTP, and CTP, and $100 \mu \mathrm{Ci}$ of $\left[\alpha-{ }^{32} \mathrm{P}\right]$ UTP for $30 \mathrm{~min}$ at $30^{\circ} \mathrm{C}$. The reaction mixtures were then treated with DNase I (0.25 unit/ $\mu \mathrm{l}$, RNase free) for $10 \mathrm{~min}$ at $30^{\circ} \mathrm{C}$ and digested with proteinase $\mathrm{K}(0.5 \mu \mathrm{g} / \mu \mathrm{l})$. After the extraction with phenol and chloroform, carrier yeast tRNA was added (100 $\mu \mathrm{g} / \mathrm{sample})$ and the RNA solution was passed over a Nick column (Pharmacia, Piscataway, NJ) to remove the unincorporated $[\alpha-$ ${ }^{32}$ P]UTP. RNA was then precipitated with $0.4 \mathrm{M}$ sodium acetate and $2.5 \mathrm{vol}$. of ethanol. The precipitate was dissolved in $100 \mu \mathrm{l}$ of $20 \mathrm{mM}$ Hepes, $\mathrm{pH} 7.4,5 \mathrm{mM}$ $\mathrm{MgCl}_{2}, 1 \mathrm{mM} \mathrm{CaCl} 2$ and digested with DNase I and proteinase $\mathrm{K}$ and extracted as described above. For complete removal of the unincorporated $\left[\alpha-{ }^{32}\right.$ P]UTP, the sample was further purified by passing over a second Nick column and the RNA was precipitated. The RNA pellet obtained from the final ethanol precipitation step was dissolved in $200 \mu \mathrm{l}$ of $20 \mathrm{mM}$ TES buffer $(\mathrm{pH}$ 7.4) containig $10 \mathrm{mM}$ EDTA and $0.2 \%$ SDS. The ${ }^{32} \mathrm{P}$ labeled RNA samples with equal amounts of radioactivities were then applied to nylon strips containing previously immobilized DNA probe. The volume of RNA solution used was sufficient to soak the nylon strip, usually $1.5 \mathrm{ml}$ in a $5 \mathrm{ml}$ scintillation vial. Hybridization was carried out $65^{\circ} \mathrm{C}$ for $36 \mathrm{~h}$. After hybridization, the strips were washed at $65^{\circ} \mathrm{C}$ for $2 \mathrm{~h}$ in $2 \times$ SSC with several changes of the wash solution, blotted dry and autoradiographed for 4 to 7 days at $70^{\circ} \mathrm{C}$ with Hyperfilm and an intensifying screen. The bands on the autoradiographies were quantified by using Bio-imaging analyzer system (BAS 2500, Fuji
Photofilm Co.). The probe immobilized on the nylon filters for the hybridization included rat CYP1A1. The cDNA probe was denatured at $100^{\circ} \mathrm{C}$ for $5 \mathrm{~min}$, rapidly cooled in ice, and loaded onto nylon filters using a slot blot apparatus. Filters were prewet with $\mathrm{H}_{2} \mathrm{O}$ and $6 \times \mathrm{SSC}$, then loaded per slot with $1 \mu \mathrm{g}$ of gel-purified cDNA insert. Filters were baked at $80^{\circ} \mathrm{C}$ for $2 \mathrm{~h}$, and trimmed close to the DNA slots prior to hybridization.

\section{Results}

\section{Effects of diallyl sulfide on 3-methylcholan- threne-induced EROD activity}

To analyze the effects of diallyl sulfide on 3methylcholanthrene-induced EROD activity, which is specific indicators of cytochrome P450 1A1 family, in mouse liver and lung, mice were treated with four injections of 3-methylcholanthrene (25 mg/kg, i.p.). EROD activity was induced by 3-methylcholanthrene treatment. EROD activity in mice treated with 3methylcholanthrene plus diallyl sulfide was significantly lower than those in 3-methylcholanthrene-treated mice. diallyl sulfide itself slightly decreased and increased EROD activity in mouse liver and lung, respectively. Therefore, Diallyl sulfide could decrease 3-methylcholanthrene-induced EROD activity in mouse liver and lung (Table 1).

\section{Effects of diallyl sulfide on 3-methylcholan- threne-induced levels of CYP1A1 mRNA}

The effect of diallyl sulfide on 3-methylcholanthreneinduced CYP1A1 mRNA was investigated in mouse liver and lung. CYP1A1 mRNA levels were increased by 3-methylcholanthrene treatment. After 3methylcholan-threne plus diallyl sulfide treatment,

Table 1. The effect of diallyl sulfide on EROD activity in 3-methylcholanthrene-treated mouse tissue microsomes. Each value represents mean \pm S.D $(\mathrm{N}=4)$.

\begin{tabular}{lrlrl}
\hline \multicolumn{1}{c}{ Treatment } & \multicolumn{2}{c}{$\begin{array}{c}\text { Liver } \\
\text { (nmol/mg }\end{array}$} & $\begin{array}{c}\text { Lung } \\
\text { (nmolein/min) }\end{array}$ & protein/min) \\
\hline Control & 0.261 & 0.035 & 0.228 & 0.023 \\
3-Methylcholanthrene & 2.740 & $0.222^{\mathrm{a}}$ & 0.462 & $0.068^{\mathrm{a}}$ \\
Diallyl sulfide & 0.218 & $0.039^{\mathrm{b}}$ & 0.265 & $0.015^{\mathrm{b}}$ \\
$\begin{array}{l}\text { 3-Methylcholanthrene } \\
+ \text { Diallyl sulfide }\end{array}$ & 0.553 & $0.092^{\mathrm{a}, \mathrm{c}}$ & 0.256 & $0.042^{\mathrm{a}, \mathrm{d}}$ \\
\hline
\end{tabular}

\footnotetext{
a significantly different from control value, $P<0.001$

${ }^{\mathrm{b}}$ significantly different from control value, $P<0.05$

${ }^{\mathrm{c}}$ significantly different from $\mathrm{MC}$ value, $P<0.001$

${ }^{d}$ significantly different from $M C$ value, $P<0.05$
} 


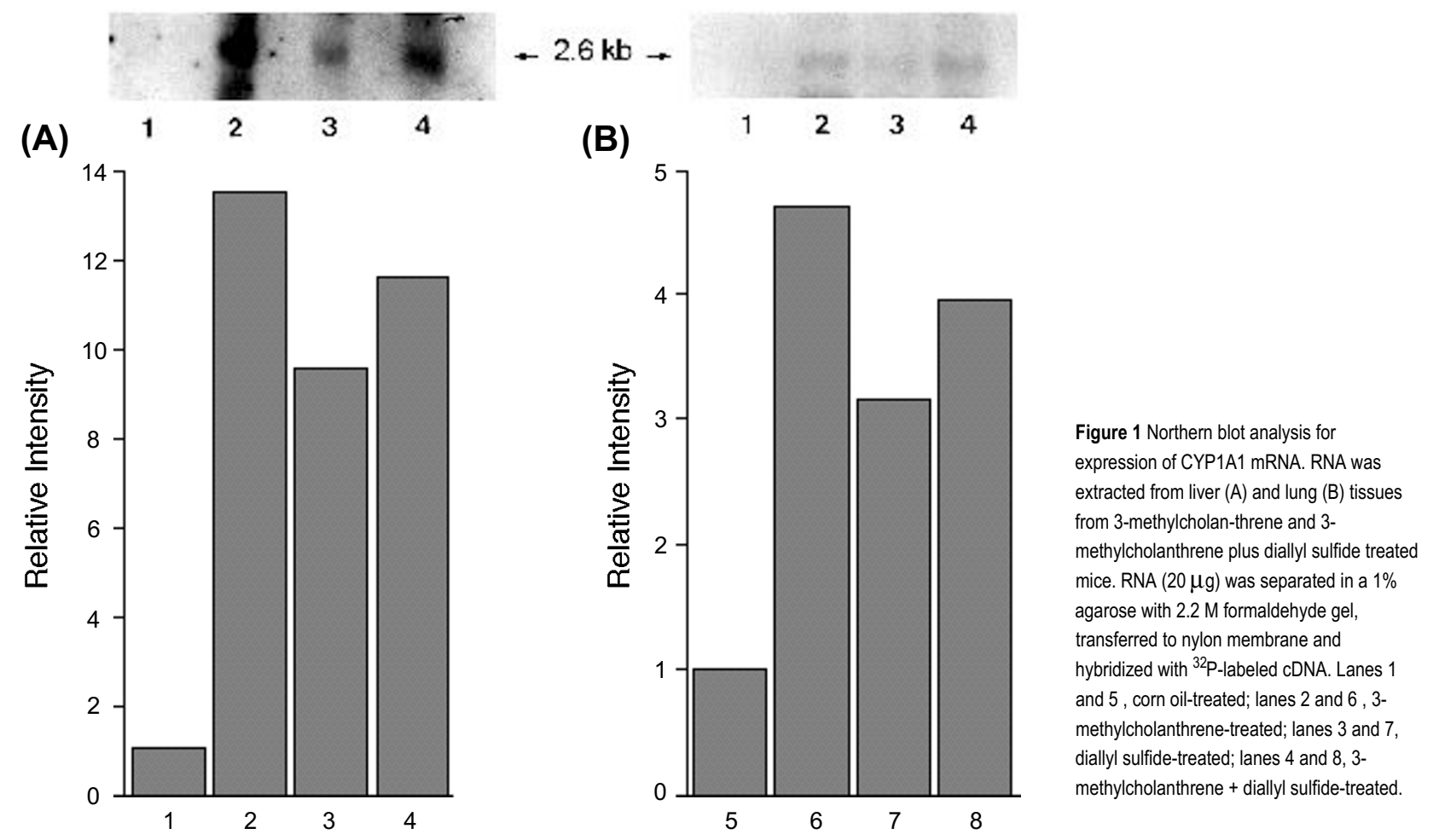

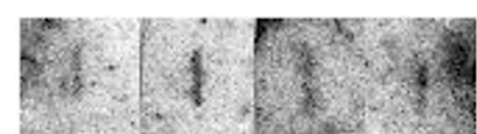

$\begin{array}{llll}1 & 2 & 3 & 4\end{array}$

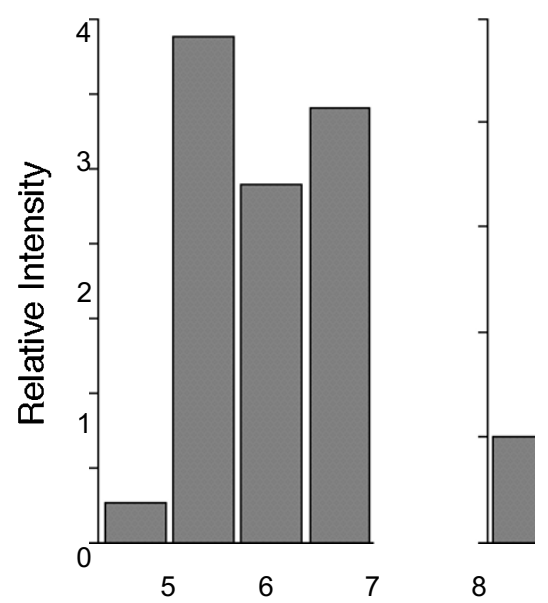

Figure 2 Nuclear run-on assay of lung nuclei. Nuclei were isolated from lung of untreated mice and mice treated with 3-methylcholanthrene and 3-methylcholanthrene + diallyl sulfide. Nuclear run-on assay was performed as described in method and transcripts hybridized to CYP1A1 cDNA. Lane 1, corn oil-treated; lane 2, 3methylcholanthrene-treated; lane 3, diallyl sulfide-treated; lane 4, 3-methylcholanthrene + diallyl sulfide-treated.
CYP1A1 mRNA levels were significantly lower than those in 3-methylcholanthrene-treated mice (Figure 1). diallyl sulfide itself increased CYP1A1 mRNA levels. Therefore, in parallel with its inhibitory effects on 3methylcholanthrene-induced EROD activity, diallyl sulfide could decrease 3-methylcholanthrene-induced CYP1A1 mRNA levels in mouse liver and lung.

In addition, induction of CYP1A1 mRNA by 3methylcholanthrene treatment and decrease of 3methylcholanthrene-induced CYP1A1 mRNA by 3methylcholanthrene plus diallyl sulfide treatment were regulated at the transcription level according to the nuclear run on assay (Figure 2).

\section{Discussion}

A diet rich in fresh fruits and vegetables has been linked in epidemiologic studies to reduced risk for various forms of human cancer, most notably colorectal cancer (National Academy of Sciences, 1982). Supporting this relationship is the recent discovery of naturally occurring chemicals in certain vegetables and fruits which inhibit the process of carcinogenesis in animals (Fiala et al., 1985). However exciting as this is, many of these newly identified dietary inhibitors of cancer have been only selectively active in interfering with induction of cancer or mutagenesis induced by 
polycyclic aromatic hydrocarbons (Newmark, 1984; Sparnins and Wattenberg, 1981). The need to discover chemical inhibitors of other structurally diverse yet equally potent carcinogens prompted this investigation of the thioethers in garlic. Members of Allium family are excellent sources of organic sulfides (Fenwick and Hanley, 1985). A long anecdotal history of the curative properties of herbs in this family has suggested that some pharmacologically active compounds could be present (Block, 1985). Investigation of organic sulfides for anticarcinogenic or chemopreventive properties was first attempted by Belman (1983) and more recently by Sparnins et al. 1986a, b). Sparnins et al. (1986a) have shown that allyl methyltrisulfide, one of the principal organic sulfides in garlic, maximally stimulated glutathione $S$-transferase activity in the A/J mice, which could account for significant inhibition of benzo(a) pyrene forestomach carcinogenesis. In another study these investigators found diallyl sulfide as well to be an effective inhibitor of lung cancer in mice (Sparmins et al., 1986).

Hepatic and extrahepatic total CYP content and CYP-dependent drug metabolism are known to decrease in animals subjected to various immunostimulatory conditions (Mannering and Deloria, 1986; Renton and Knickel, 1990). Proposed mechanisms for this effect include destruction of CYP enzymes by free radicals (Ghezzi et al., 1985), reduced CYP mRNA translation (Gooderham and Mannering, 1986; Renton and Knickel, 1990), and reduced CYP mRNA levels (Renton and Knickel, 1990). In the present study, diallyl sulfide itself slightly decreased and increased EROD activity in mouse liver and lung, respectively, and increased CYP1A1 mRNA level. In contrast to our findings, a recent study by Harber et al. (1995) revealed that diallyl sulfide enhanced rat hepatic microsomal EROD activity. In other work (Dragnev et al., 1995), diallyl sulfide exhibits minimal effects on the levels of CYP1A subfamily in rats. However, it is difficult to compare these findings with those in this study, because of different strains of animals used. In addition, we demonstrated that the induction of CYP1A1 mRNA and EROD activity by polycyclic aromatic compounds such as 3-methylcholanthrene is greatly reduced in mouse lung co-treated with diallyl sulfide. The modulation of carcinogen-metabolizing CYP expression by diallyl sulfide may have relevance to the process of chemical carcinogenesis and may contribute to individual variations in cancer susceptibility. Diallyl sulfide, by modifying CYP1A1 expression, may modulate the ability of this CYP to activate and/or detoxify carcinogens. There is an evidence that correlates increased inducibility of CYP1A1 activity with increased susceptibility to some forms of cancer in man (Kellermann et al., 1973; Guirgis et al., 1976; Trell et al., 1976; Kouri et al.,
1982). Genetic, environmental and behavioral factors are known to influence individual susceptibility to some forms of chemically induced cancer. For example, cigarette smokers are known to have chronic lung inflammation (Linden et al., 1989). The degree of inflammation, however, varies from individual to individual (Linden et al., 1989), and therefore could result in differences among individuals in lung CYP1A1 expression and thus, carcinogen activation and/or detoxification.

\section{References}

Aoyama, T., Yamano, S., Guzelian, P., Gelboin, H. V. and Gonzalez, F. J. (1990) Five of 12 forms of vaccinia virus-expressed human hepatic cytochrome P450 metabolically activate aflatoxin B1. Proc. Natl. Acad. Sci. U.S.A. 87: 4790-4793

Belman, S. (1983) Onion and garlic oils inhibit tumor formation. Carcinogenesis(Lond.) 4: 1063-1065

Block, E. (1985) The chemistry of garlic onion. Sci. Am. 252: 114-119

Black, S. D. and Coon, M. J. (1987) P-450 cytochromes: structure and function. Adv. Enzymol. 60: 35-87

Burke, M. D., Thompson, S., Elcombe, C. R., Halpert, J., Haapararita, T. and Mayer, R. T. (1974) Ethoxyresorufin: direct fluorimetric assay of a microsomal-O-dealkylation which is preferentially inducible by 3-methylcholanthrene. Drug. Metab. Dispos. 2: 583588

Burke, M. D., Thompson, S., Elcombe, C. R., Halpert, J., Haapararita, T. and Mayer, R. T. (1985) Ethoxy-, pentoxy- and benzyloxyphenoxa-zones and homologue: A series of substrates to distinguish between different induced cytochrome P-450. Biochem. Pharmacol. 34: 3337-3345

Butler, M. A., Guengerich, F. P. and Kadlubar, F. F. (1989a) Metabolic oxidation of the carcinogens 4-aminobiphenyl and 4,4'-methylene-bis (2-chloroaniline) by human hepatic microsomes and by purified rat hepatic cytochrome P450 monooxygenases. Cancer Res. 49: 25-31

Butler, M. A., Iwasaki, M., Guengerich, F. P. and Kadlubar, F. F. (1989b) Human cytochrome $\mathrm{PA}$ (P-450IA2), the phenacetin 0-deethylase, is primarily responsible for the hepatic 3-demethylation of caffeine and $\mathrm{N}$-oxidation of carcinogenic arylamines. Proc. Natl. Acad. Sci. U.S.A. 86: 7696-7700

Chomczynski, P. and Sacchi, N. (1987) Single-step method of RNA isolation by acid guanidinium thiocyanate-phenol-chloroform extraction. Anal. Biochem. 162, 156-159

Dragnev, K. H., Nims, R. W. and Lubet, R. A. (1995) The chemopreven-tive agent diallyl sulfide a structurally atypical phenobarbital-type inducer. Biochem. Pharmacol 50: 2099-2104

Fenwick, G. R. and Hanley, A. B. (1985) The genus Allium-Part 3, CRC Crit. Rev. Food Sci. Nutr. 23: 1-73

Fiala, E. S., Reddy B. S. and Weisburger, J. H. (1985) Naturally occurring anticarcinogenic substances in food stuffs. Annu. Rev. Nutr. 5: 295-321

Ghezzi, P., Bianchi, M., Gianera, L., Landolfo, S. and Salmona, M. (1985) Roles of reactive oxygen intermediates in the interferon-mediated depression of hepatic drug metabolism and protective effect of $\mathrm{N}$-acetyl cysteine in mice. Cancer Res. 45: 34443447

Gooderham, N. J. and Mannering, G. J. (1986) In Development of Drugs and Modern Medicine (Gorrod, J. W., Gibson, G. G., Mitchard, M., eds.), pp. 339-343, Ellis Horwood, Chichester

Guirgis, H. A., Lynch, H. T., Mate, T., Harris R. E., Wells. I., Caha, L., Anderson, J., 
Maloney, K. and Rankin, L. (1976) Aryl-hydrocarbon hydroxylase activity in lymphocytes from lung cancer patients and normal controls. Oncology 33: 105-109

Haber, D., Siess, M.-H., Canivenc-Lavier, M.-C., Le Bon, A.-M. and Suschetet, M. (1995) Differential effects of dietary diallyl sulfide and diallyl disulfide on rat intestinal and hepatic drug-metabolizing enzymes. J. Toxicol. Environ. Health. 44: 423-434

Hong, J. Y., Pan, J. M., Dong, Z. G., Ning, S. M. and Yang, C. S. (1987) Regulation of $\mathrm{N}$-nitrosodimethylamine demethylase in rat liver and kidney. Cancer Res. 47: 5948-5953

Kellermann, G., Shaw, C. R. and Muyten-Kellermann, M. (1973) Aryl hydrocarbon hydroxylase inducibility and bronchgenic carcinoma. New Engl. J. Med. 289: 934-937

Kouri, R. E., McKinney, C. E., Slomiany, D. J., Snodgrass, D. R., Wray, N. P. and Mclemore, T. L. (1982) Positive correlation between high aryl hydrocarbon hydroxylase activity and primary lung cancer as analyzed in cryopreserved lymphocytes. Cancer Res. 42: 5030-5037

Linden, M., Hakansson, L., Ohlsson, K., Sjodin, K., Tegner, H., Tunek, A. and Venge, P. (1989) Glutathione in bronchoalveolar lavage fluid from smokers is related to humoral markers of inflammatory cell activity. Inflammation 13: 651-658

Lowry, O. H., Rosebrough, N. J., Farr, A. L. and Randoll, R. J. (1951) Protein measurement with the folin-phenol reagent. J. Biol. chem. 193: 265-275

Mannering, G. J. and Deloria, L. B. (1986) The pharmacology and toxicology of the interferons: an overview(Review). Annu. Rev. Pharmacol. Toxicol. 26: 455-515

National Academy of Sciences. (1982) Diet, Nutrition and Cancer. National Academy Press, Washington DC

Nebert, D. W., Nelson, D. R., Coon, M. L., Estabrook, R. W., Feyereisen, R., FujiiKuriyama, Y., Gonzalez, F. J., Guengerich, F. P., Gunsalus, I. C., Johnson, E. F., Loper, J. C., Sato, R., Waterman, M. R. and Waxman, D. J. (1991) The P450 superfamily: Update on new sequences, gene mapping, and recommended nomenclature. J. Biochem. 10: 1-14

Newmark, H. L. (1984) A hypothesis for dietary components as blocking agents of chemical carcinogenesis: plant phenolics and pyrrole pigments. Nutr. Cancer. 6: 58-70

Renton, K. W. and Knickel, L. C. (1990) Regulation of hepatic cytochrome P450 during infections disease (Review). Can. J. physiol. Pharmacol. 68: 777-781
Santhanam, K. and Lotlikar, P. D.(1989) Effect of beta-naphthoflavone on the metabolism of aflatoxin $B_{1}$ in hamsters. Cancer Lett. 45: 129-134

Schebler, U., Hagenbuchle, O., Wellauer, P. K. and Pittet, A. C. (1983) Two promoters of different strengths control the transcription of the mouse alpha-amylase gene amy-la in the parotid gland and the liver. Cell 33: 501-508

Sparnins, V. L. and Wattenberg L. W. (1981) Enhancement of glutathione Stransferase activity of the mouse forestomach by inhibitors of benzo(a)pyrene-induced neoplasia of the forestomach. J. Natl. Cancer Inst. 66, 769-771

Sparnins, V. L., Mott, A. W., Barany, G. and Wattenberg, L. W. (1986a) Effects of allyl methyl trisulfide on glutathione $S$-transferase activity and BP-induced neoplasia in the mouse. Nutr. Cancer 8: 211-215

Sparnins, V. L., Barany, G. and Wattenberg, L. W. (1986b) Effects of organosulfur compounds from garlic and onions on benzo(a)pyrene-induced neoplasia and glutathione S-transferase activity in the mouse. Carcinogenesis (Lond.) 9: 131-134

Trell, E., Korsgaard, R., Hood, B., Kitzing, P., Norden, G. and Simonsson, B. G. (1976) Aryl hydrocarbon hydroxylase inducibility and laryngeal carcinomas. Lancet 2: 140

Zelenka, P. S., Pallansch, L. A. and Vatol, M. (1989) Nuclear run-on transcription from primary embryonic lens tissue. Dev. Biol., 132: 69-72 